Michael J. Bautista MD,

Brian S. Kuwahara MD FRCPC, Charles U Henderson MD, FRCPC

\title{
Transcutaneous oxy- gen monitoring in an infant undergoing tracheoesophageal fistula repair
}

A case report is presented describing the clinical usefulness of transcutaneous oxygen $\left(\mathrm{PtCO}_{2}\right)$ monitoring in an infant undergoing tracheoesophageal fistula repair. Its use allowed early and precise recognition of hypoxaemia during periods of surgical manipulation. During periods of hypoxaemia, there were no assaciated cardiovascular changes or changes in routine monitoring modalities. Clinical use of $\mathrm{PtcO}_{2}$ may detect early hypoxaemia and thus allow for correction before the appearance of changes in vital signs.

Hypoxaemia is a major cause of morbidity and mortality during anaesthesia. Its early detection and correction is of paramount importance to all anaesthetists. Transcutaneous oxygen $\left(\mathrm{PtcO}_{2}\right)$ monitoring enables reliable continuous readings of oxygen tension at the "arterialized" capillary level. Its use, and limits of use, have been known to neonatologists for years ${ }^{1,2}$ yet surprisingly little report of its practical benefits in paediatric anaesthesia have appeared.

The following case report describes the usefulness of $\mathrm{PtcO}_{2}$ monitoring in an infant undergoing repair of tracheoesophageal fistula (TEF).

\section{Key words}

ANAESTHESIA: paediatric neonatal: SURGERY: tracheoesophageal fistula repair: MONITORING: noninvasive, transcutaneous $\mathrm{O}_{2}$.

From the Department of Anaesthesia, Dr. Charles A. Janeway Child Health Centre, St. John's, Nfld, , A1A 1RB, where correspondence should be addressed to Dr. Kuwahara.

\section{Case history}

The patient was a male, Caucasian, full-term infant whose birth weight was $3.96 \mathrm{~kg}$, born by Caesarian section to a 22-year-old primigravida. The mother had not sought prenatal care initially. During pregnancy, she had experienced a $25 \mathrm{~kg}$ weight gain and pre-eclampsia had been diagnosed in the final weeks. This, however, did not require hospitalization.

At birth, the Apgar scores were seven at one minute and nine at five minutes. The patient required oxygen by mask. On examination there were right-sided intercostal indrawing and excessive airway secretions requiring vigorous aspiration. Other physical findings included an undescended testicle and a pansystolic murmur consistent with a small ventricular septal defect.

A nasogastric tube could not be passed and chest $x$-ray revealed that the tube was located in the upper oesophagus. There was gas in the stomach. A diagnosis of tracheoesophageal fistula (TEF) was made.

Therapy with ampicillin and gentamicin was started, a sump drain placed in the upper oesophagus and oxygen therapy initiated. The patient was then transferred to our hospital.

Laboratory results were; haemoglobin $197 \mathrm{~g}$. $\mathrm{L}^{-1}$, WBC $21.0 \times 10^{9} / \mathrm{L}$, platelets $288 \times 10^{9} / \mathrm{L}$, serum sodium $134 \mathrm{mmol} \cdot \mathrm{L}^{-1}$, potassium $5.0 \mathrm{mmol}$. $\mathrm{L}^{-1}$, chloride $98 \mathrm{mmol} \cdot \mathrm{L}^{-1}$, calcium $2.4 \mathrm{mmol}$. $\mathrm{L}^{-1}$, glucose $4.7 \mathrm{mmol} \cdot \mathrm{L}^{-1}$. Blood gas analysis of a capillary sample showed the $\mathrm{pH}$ to be $7.41, \mathrm{PCO}_{2}$ $33.5 \mathrm{mmHg}$, bicarbonate $22.2 \mathrm{mmol} \cdot \mathrm{L}^{-1}$, and $\mathrm{PO}_{2}$ $58.9 \mathrm{mmHg}$ with an $\mathrm{FIO}_{2}$ of 0.50 . A preoperative echocardiogram showed normal intracardiac anatomy with no patent ductus arteriosus.

On the same day, the patient was taken to the 


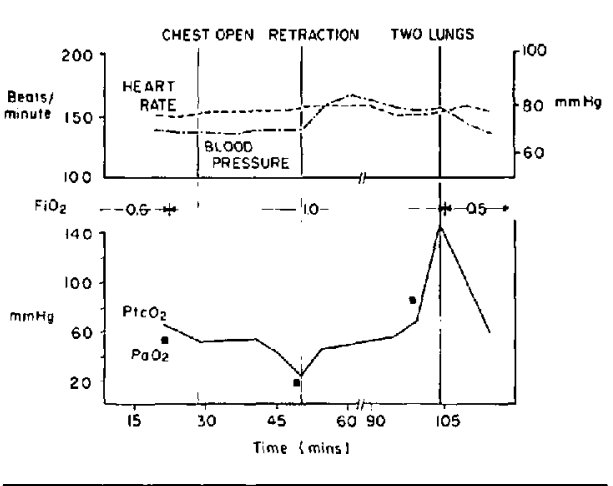

FIGURE Graphic depiction of the anaesthetic course of a neonate undergoing tracheoesophageal fistula repair. Heart rate in beats per minute (--), blood pressure in $\mathrm{mmHg}(-\cdot-)$, $\mathrm{PtcO}_{2}$ in $\mathrm{mmHg}(\longrightarrow)$, and $\mathrm{PaO}_{2} \mathrm{mmHg}_{(-)}$vs time in minutes are shown. See text for details.

operating room for repair of the TEF. Baseline vital signs were: respiratory rate 46 , heart rate 134 , and blood pressure $62 \mathrm{mmHg}$ systolic.

Atropine $0.04 \mathrm{mg}$ was given intravenously and the patient was intubated awake, using a $3 \mathrm{~mm}$ Portex endotracheal tube. Fentanyl $(10 \mu \mathrm{g})$ and pancuronium $(0.03 \mathrm{mg})$ were then given intravenously; anaesthesia was maintained with fentanyl and muscle relaxation with pancuronium. Intermittent positive pressure ventilation was maintained with heated and humidified oxygen $\left(\mathrm{FlO}_{2} 0.6-1.0\right)$ and nitrogen using a Sechrist ventilator model IV-100B. Body temperature was maintained within normal limits.

Intraoperative monitoring included an electrocardiogram, a stethoscope over the dependent left lung, rectal temperature, and an arterial line in the right radial artery. The $\mathrm{PtcO}_{2}$ was measured using a Kontron cutaneous oxygen monitor Model 820 using a Clark type electrode, which was calibrated and placed on the anterior abdominal wall in the left lower quadrant.

The patient was placed in the left lateral position and a transpleural approach made through a rightsided thoracotomy. No difficulties were encountered until forceful retraction of the lung was performed to expose and isolate the fistula. At this time the $\mathrm{PtcO}_{2}$ dropped from readings ranging from 50 to $60 \mathrm{mmHg}$ to $25 \mathrm{mmHg}$, despite an increase in the $\mathrm{FlO}_{2}$ from 0.6-1.0 (Figure). An arterial blood gas sample taken at the same time and analyzed by an Instrumentation Laboratory model 1312 Blood Gas Manager showed the $\mathrm{pH}$ to be $7.08, \mathrm{PCO}_{2}$ $57.1 \mathrm{mmHg}$, bicarbonate $17.4 \mathrm{mmol} \cdot \mathrm{L}^{-1}$, and $\mathrm{PO}_{2}$ $21 \mathrm{mmHg}$. There were no associated changes in heart rate, blood pressure, breath sounds or heart sounds. The surgery was interrupted to allow recovery from the hypoxaemia, and the ventilator adjusted to compensate for retraction. The operation then proceeded without further complications with complete correction of the lesion. The chest was closed after placement of a right-sided chest drain.

Postoperatively, the baby was ventilated mechanically for three days and given parenteral nutrition. He began oral feeding seven days postoperatively after a barium swallow showed no leakage at the anastomotic site. He was discharged on the twelfth postoperative day.

\section{Discussion}

Transcutaneous oxygen monitoring is being used increasingly in anaesthesia practice ${ }^{2-4}$ particularly in neonates ${ }^{5}$ in whom hypoxaemia and oxygen toxicity $^{6}$ are major concerns.

Widely used in the neonatal intensive care unit, problems have been reported with the technique in the operating room because of interference by halothane, nitrous oxide, ${ }^{7}$ temperature control ${ }^{8}$ and hypotension. ${ }^{1,2,9,10}$ Others have not found anaesthetic gases to be a problem. ${ }^{2}$ In our case, by using a Sechrist ventilator, and maintaining anaesthesia with relaxant and narcotic, we avoided problems encountered with nitrous oxide and halothane. Normothermia was maintained during surgery. Good correlation was established between $\mathrm{PtcO}_{2}$ and $\mathrm{PO}_{2}$ as measured by arterial blood gases.

Other reports ${ }^{2-5,11}$ have described good correlation between $\mathrm{PtcO}_{2}$ and $\mathrm{PO}_{2}$, but few mention whether changes are followed by adverse changes in other monitoring modalities. Peabody and Neese et al. ${ }^{12}$ did show an association between increased heart rate variability and hypoxic fluctuation in $\mathrm{PtcO}_{2}$ in infants not receiving theophylline.

Of note in our patient was the appearance of hypoxaemia by both $\mathrm{PtCO}_{2}$ and $\mathrm{PO}_{2}$ prior to any discemible change in routine monitoring modalities, i.e., blood pressure, electrocardiogram or dependent lung breath sounds. It is felt that significant cardiovascular changes were avoided by early detection of hypoxaemia and interruption of the 
surgical procedure, with adjustment of mechanical ventilation.

The absence of changes in heart rate and blood pressure associated with moderately severe hypoxaemia has been previously documented in adults undergoing thoracotomies. ${ }^{4}$ In neonates, others have detected such episodes of hypoxemia with the use of $\mathrm{PtcO}_{2},{ }^{5}$ It has been postulated that neonates are resistant to cardiovascular depression from hypoxia because of ATP generation that can occur in spite of anaerobic metabolism. ${ }^{13}$ It appears infants can decrease oxygen consumption by 15 to 20 per cent ${ }^{14,15}$ during episodes of hypoxia.

We have found $\mathrm{PtcO}_{2}$ monitoring a valuable adjunct to our practice and have had no complications related to its use; monitoring of the $\mathrm{PO}_{2}$ has been stressed before for infants undergoing TEF repair. ${ }^{16} \mathrm{PtcO}_{2}$ monitoring has the advantage of making available continuous "real time" assessment of $\mathrm{PO}_{2}$ which is particularly useful during periods of surgical manipulation when hypoxaemia and hyperoxaemia can go unrecognized using intermittent blood gas sampling. ${ }^{5}$ One suspects that more episodes of hypoxaemia occur in neonates than can be appreciated without $\mathrm{PtcO}_{2}$ monitoring.

\section{Acknowledgements}

We would like to acknowledge the assistance of Dr. R. Carachi, Dr. H. J. Manson, A. Osborne, C. Sheehan, and Judy Curtis, Geriann Quan and Mary Gellately, Anaesthesia Department secretaries.

\section{References}

1 Peabody JL, Gregory GA, Willis MM, Tooley $W H$. Transcutaneous oxygen tension in sick infants. Am Rev Respir Dis 1978; 118: 83-7.

2 Tremper, $K K$. Transcutaneous $\mathrm{PO}_{2}$ measurement. Can Anaesth Soc J 1984; 31: 664-77.

3 Rafferty TD, Marrero O, Nardi D, Schachter EN, Mentelos $R, N g$ eow $Y F$. Transcutaneous $\mathrm{PO}_{2}$ as a trend indicator of arterial $\mathrm{PO}_{2}$ in normal anesthetized adults. Anesth Analg 1982; 61: 252-5.

4 Tremper KK, Konchigeri HN, Cullen BF, Kapur $P A$, Thangathurai $D$, Percival $C$. Transcutaneous monitoring of oxygen tension during one-lung anaesthesia. J Thorac Cardiovasc Surg 1984; 88: 22-5.

5 Finer NN, Stewart AR. Continuous transcutaneous oxygen monitoring in the critically ill neonate, a controlled clinical trial. Crit Care Med 1980; 8: 31923.

6 Betts EK, Downes J, Schaffer DB, Johns R. Retrolental fibroplasia and oxygen administration during general anaesthesia. Anesthesiology 1977; 47: 518-20.

7 Eberhard $P$, Mindt $W$, Interference of anesthetic gases at oxygen sensors. Birth Defects 1979; 15 : $65-74$.

8 Huch R, Huch A, Albani $M$ et al. Transcutaneous $\mathrm{PO}_{2}$ monitoring in routine management of infants and children with cardiorespiratory problems. Pediatrics 1976; 57: 681-90.

9 Peabody $J L$, Willis MM, Gregary GA, Tooley $W H$, Lucey JF. Clinical limitations and advantages of transcutaneous oxygen electrodes. Acta Anaesthesiol Scand Suppl 1978; 68: 76-82.

10 Versmold HT, Linderkamp O. Holzmann $M$, Strohhacker I, Riegel K. Transcutaneous monitoring of $\mathrm{PO}_{2}$ in newborn infants: where are the limits? Influence of blood pressure, blood volume, blood flow, viscosity and acid base state. Birth Defects 1979; 15: 285-94.

11 Dennhardt R, Fricke M, Mahal S, Huch A, Huch R. Transcutaneous $\mathrm{PO}_{2}$ monitoring in anaesthesia. Europ J Intensive Care Med 1976; 2: 29-33.

12 Peabody JL, Neese AL, Philip AGS, Lucey JF, Soyka $L F$. Transcutaneous oxygen monitoring in aminophylline-treated apneic infants. Pediatrics 1978; 62: 698-701.

13 Jarmakani JM, Nagatomo T, Nakazawa $M$, Langer $G A$. Effect of hypoxia on myocardial high-energy phosphates in the neonatal mammalian heart. Am J Physiol 1978; 235: H475-H481. 
14 Fisher DJ. Oxygenation and metabolism in the developing heart. Seminars in Perinatology 1984; 8 : 217-25.

15 Rudolph $A M$. Oxygenation in the fetus and neonate - a perspective. Seminars in Perinatology 1984; 7: 158-67.

16 Morray J. Anesthesia in thoracic surgery. In: Gregory GA, Pediatric Anesthesia. New York: Churchill-Livingstone, 1983.

\section{Résumé}

Un cas est présenté décrivant l'utilité clinique de la surveillance transcutanée de la saturation en oxygène $\left(\mathrm{PtcO}_{2}\right)$ chez un enfant subissant une réparation d'une fistule trachéoesophagienne. Son utilisation a permis une détection précoce et précise de l'hypoxémie lors des manipulations chirurgicales. Lors des épisodes d' hypoxémie on n'observait aucun changement cardiovasculaire ou altérations des données avec les techniques de surveillance routinières. L'utilisation clinique de la $\mathrm{PtcO}_{2}$ peut détecter précocément une hypoxémie et ainsi permettre une correction avant l'apparition de change. ments dans les signes vitaux. 